\title{
Racism in Football: A Narrative Path
}

\author{
Mauro Maia Laruccia1, Valdenise Leziér Martyniuk ${ }^{2}$ \\ ${ }^{1}$ Business School, Pontifícia Universidade Católica de São Paulo and Fundacentro, São Paulo, Brazil \\ ${ }^{2}$ School of Communication, Pontifícia Universidade Católica de São Paulo, São Paulo, Brazil \\ Email: mauro.laruccia@gmail.com
}

How to cite this paper: Laruccia, M. M., \& Martyniuk, V. L. (2016). Racism in Football: A Narrative Path. Advances in Journalism and Communication, 4, 103-112. http://dx.doi.org/10.4236/ajc.2016.44010

Received: April 24, 2016

Accepted: December 2, 2016

Published: December 5, 2016

Copyright $\odot 2016$ by authors and Scientific Research Publishing Inc. This work is licensed under the Creative Commons Attribution International License (CC BY 4.0).

http://creativecommons.org/licenses/by/4.0/

\begin{abstract}
The article discusses the narrative occurred in an episode of the Brazilian sports scene, which raised the issue of racism in football. The importance and significance of researching racism in Brazil is due, among others, that most people in Brazil are white miscegenated population. In Brazil, it should be an obligation of all citizens, regardless of their origin or ethnicity. Therefore, it takes as the object of Gremio soccer support images of racism published on August 29, 2014 by http://ESPN.com.br. It was used Greimasian semiotics as the methodology, specifically, Eric Landowski (2009) socio-semiotics developments support to understanding relationships between subjects and their sense regimes and interaction. We conclude that based on social narratives presented with stereotypes historically constructed on critical conscious society acts. In this context, the media amplify acts of racism and controversy, which may pass unnoticed by the players without this visibility.
\end{abstract}

\section{Keywords}

Discursive Semiotics, Racism, Football, Socio-Semiotics, Accident

\section{Introduction}

This work has the objective to analyze the narratives involved in the episode occurred in August 2014, in which a supporter of a Porto Alegre's club spoke out against a player from the opposing team, having been caught in a racist speech to the athlete. The work is divided into two parts.

In the first, we discuss the introduction of football in Brazil and racial prejudice related to it. Racial prejudice is constant not only in a society in general, as well as in football, which can be thought of as a paradigmatic expression of wishes, desires and frustrations of companies and individuals whose identities are related to the sport.

Second, we discuss the subject of fan interactions with their peers, with the oppo- 
nent and society in general, revealing the set simulacra. It takes as object images in video supporter of Grêmio Football Portoalegrense, published on August 29, 2014, by http://ESPN.com.br. Methodologically, we used greimasian semiotics and Eric Landowski socio-semiotics. Choosing narrative analysis allows us to understand how relationships between individuals complexity as the units of analysis of meaning creation in their lives as narratives or discourse.

\section{Racism in Football}

Soccer, considered as defining the national identity in Brazil, was brought in the early twentieth century to Brazil by British for the elite of the children of industrialists who had gone on business or studies to England. From elite sport, football quickly began to expand the popular classes, with factories and floodplains. Promoted by the cultural industry through the sports press, the Brazilian football has grown with the emergence of industrial cities. In a society with strong rancid slave, this sport was introduced under the sign of new, and with the values of individualism and egalitarianism, called up, according to Roberto da Matta (1994: p. 13), the two key points capitalism:

"The first is the discipline of the masses that sport teaches and reaffirmed when demands that all should come to the stadium at certain times, properly paying the entries. The second is its close connection with the idea of fair play, for sport trivializes the idea of victory and defeat. Now this socialization for failure and success, this trivialization of loss, poverty, and bad luck, could only take place in a transformed society, as Karl Polanyi, the market encompasses everything and make belief."

Despite being a sport whose key feature is the maximization of body performance and domestication, football establishing a temporality and ambiance that is affectional of order, implemented by the memory of fans able to remember moves of his idols, fault and judges' evil meaning sharing a common identity. Roberto da Matta says that football introduces a discontinuity, a break in linear time profit and efficiency. Indicating that the sport has an instrumental or practical side that allows us to make things and promote wealth; but it also has a huge expressive axis and symbolic that just says and with the rituals, reveals who we are (Damatta, 1994).

If for some football can still be thought of as opium of the people; for others, it is a social integration code, in which people historically excluded could not only share with the elite of the nation-state symbols such as the flag, the anthem, and the national colors but also feel victorious. Football is revelatory of Brazilian society, and as such, dramatizes its features. It is as if we have a ray of society from the way it absorbs and experiences this sport, so important as to be essential to think herself. Presently, football proves that you can relate values and cultural sites, born with a vision of the traditional and particularistic world, with a modern and universalist logic (Damatta, 1994). 
To be incorporated into different groups, becoming a defining national identity, this sport has much to say about the social relations of Brazil. Football was built as a ground which abounds both race prejudice examples (manifest in the exclusion and segregation schemes) and as a black integration mode (for assimilation or admission). Thus, in the late nineteenth and early twentieth century, racial miscegenation was seen by the establishment as an explanation for the Brazilian delay, from the 1930s, with Gilberto Freyre and journalist Mario Filho, the miscegenation ideology wins major and goes on to explain the "aphrodisiac football" Brazil instead the "Apollonian football" practiced by other countries. In the words of Helal, if Mario Filho:

"One of the founders of sports journalism in Brazil was instrumental in the use of football as a means to build an idea of the Brazilian nation. Freyre, in turn, (...) praise racial miscegenation and claims she founded a certain style of play that would be typical of Brazil-a Dionysian dance, which later came to be called 'football-art'. Freyre and son were key actors of the success of the "country of football" (Helal, 2011: p. 29).

From there, the black and mulatto become part of a positive vision of national identity; without, however, not be simulacrum through notions about the nature of his race, as the "irrationality", "impulsivity", "excess", "musicality", "ginga", "art", "malice” etc. (Gordon Jr., 1996). Several authors, including Abrahão \& Soares (2009), demonstrate that the action that expresses admiration the black in football served to the positive construction of national identity, but also to maintain the social hierarchy derived from slavery. In the words of these authors, the supposed superiority is shown by black people for sports, the white of the speech indicates ultimately places that African descendant should occupy in Brazilian society (Abrahão \& Soares, 2009). That is, before the rational aspect of the white, the black outbid with a supposed innate emotionality derived from their irrationality. Thus, the white belong to the sphere of culture, black lie in nature. This bias reinforces the presence of racism in Brazilian culture, that is, forms of black integration would be more subject to the admission arrangements and segregation than the absolute term of assimilation (Landowski, 2002).

Gordon Jr. (1996) states that although football has been a key element for a social and economic rise of blacks and mulattos who contribute for racial democracy, nevertheless still exists racist ideology in Brazil. Despite the black situation in Brazilian football has improved after World War II, with the end of fascism, prejudice still exists. Since then, another form of racism, with two black categories in football jargon: "My club" and "adversary club." While my club was loved and defended, being treated socially as white; the other club still being the same "black", "dirty", "brats", "characterless" as before. These principles led to assume that the black had only ascended socially because he had ceased to be black. That is when they leave act and live like blackeither by purchasing metaphysically white characteristics (soul), either to seek to adopt a typical white social behavior (more easily acquired with enrichment and with the consumption pattern changes). Despite the change in the role, blacks still suffer racism 
and often find themselves in discrimination situation. In the legislative field little has changed since slavery was abolished in 1888 . The reality remains the hard way. From the beginning, many were invited to enter Brazil, the black was forced to work as a slave, citing laws such as the Vagrancy, the ban on poultry and the impediment to land ownership.

Currently, social relations with regard to representations of the black race in Brazil are still ambivalent and expresses soccer exemplary manner such feature. Much of this relates to the myth of racial democracy that still prevails in the Brazilian imagination, and whose reverberation is presented in football through a "proper way" to play in Brazil, due to the miscegenation of the country. In contrast, at the USA prejudice race concerns the origin and in Brazil is related to appearance through the assimilationist ideology, which is expected to whitening skin color to create something new, sui generis, through the mixing of ethnic groups.

When the prejudice of race is exercised in relation to appearance, that is, when it takes a pretext for its manifestations physical traits of individuals, physiognomy, gestures, accent, it said that is the mark; when just the assumption that the individual is descended from a certain ethnic group to suffer the consequences of prejudice, it is said that is the origin.

Due to prejudice marks and its assimilationist ideology, the Brazilian sports media only highlights stories about racism in football on home soil when a case between players, fans, coaches, and sometimes even leaders (Nogueira, 2007; Tonini, 2012: p. 438), some large Brazilian football club, or when it involves foreign athletes, as Argentines. The news fans of European clubs that mimic monkeys and/or throw bananas at players during the championships are commonplace in national headlines, but generally do not go beyond the sports media. The exception was the racism suffered by Barcelona player Daniel Alves. This could be one of many if not for his reaction and the effect that the case had. Differently from others, he became an event, surpassing the sports media, being matters of controversy and debates among various sectors of society. In the wake of this, now we discussed the case of Gremio soccer support, which reheated the debate at the national level.

The racism issue is still difficult for many people in Brazil, especially when it comes to the law. Even with legislation deployment against racism, there are those who do not differentiate between certain attitudes and practice of racist crime or not. One of the biggest confusions that people can make is to confuse racism and the racial slur. Racial slur occurs when spoken or expressed offenses certain types of people, taking as an example calling a black "monkey". The racial slur charge allows bail and is worth a maximum of eight years, although not usually pass the three years. Racism is more serious, considered a non-bailable and imprescriptible crime. For the crime be considered racism, you have to belittle someone's race, either by denying access to a given site, job denial based on a person's race. Briefly, racism prevents the exercise of the practice of a right that the person has. The racial slur is determined by the offense to people by race. 


\section{Procedures and Methods}

This study analyzed the videosequence and narrative, taking as theoretical approach the principles of discursive semiotics (according to A. J. Greimas and his followers), specifically those relating to the interactions between subjects developed in socio-semiotic. The three Landowski $(1992,2002,2006)$ contributions are valuable for the elucidation of the analysis: the inclusion and exclusion schemes (discussion of identities at stake in the issue of racism); the interaction and sense regimes (which support the understanding of the relationships developed in the narratives enthralled by twisters, polemical target) and, finally, visibility schemes, where grasp the implications of media participation in the production of meaning in the social context.

The generative path direction is given in three levels, from the concrete to the abstract, giving to do, deconstruction operated by analysis that the patterns and themes relate to the deepest values, of which the text applies to do belief in the competence of its destinators. In the discursive level, more concrete, we will seek to identify which figuration is elected in enunciative choices to compose the discourse of racism in football stadiums, a central theme of our study. On the narrative level, the heart of the analysis, interpersonal relations are understood. At the fundamental level, are located in the social values at stake in the axiology of the fact described by the media.

The analyzed image presents a putting standpoint outstanding values that generate controversy. Thus, it is important to consider where the subject of the speech states what their role in the act of enunciation and under what conditions this discourse was produced since it is a media product that is observed. We consider here the expanded notion of text given by discursive semiotics and therefore the images as part of a syncretic text that is the key feature of video production.

Methodologically, research typology divides into three categories: the aims, about the procedures and how to approach the problem (Raupp \& Beuren, 2006). The aims consist of a descriptive research, the procedures, in which it decides which way collect the data, we use the greimasian Semiotics and the corpus of Gremio supporter of images (Figure 1) published on august 29, 2014 by http://ESPN.com.br (ESPN, 2014). In this sense, this research approach to the problem is the qualitative, since it operationalizes values, beliefs, habits, attitudes, representations and opinions, deepening the complexity of particular facts and processes and specific to individuals and interrelated groups. In the qualitative study, the legitimacy of inferred propositions is not necessarily the number of cases or respondents, but in dealing with the essential findings of regularities explanation (Fernandes, 1980; Lima, 2014).

\section{Analysis and Discussion of the Corpus}

The analyzed corpus was the Gremio fan image obtained from transmission decoupage of the football game on ESPN, as shown in Figure 1. The video begins showing an athlete who complains to the referee, while the narrator and TV commentator try to understand what is happening between played and fan to position the viewers. The scenes alternate between general plans of the crowd, camera shots that run along the front 


\title{
Torcedora racista do Grêmio é afastada do trabalho, diz jornal
}

\author{
Publicado em 29/08/2014, 11:03/Atualizado em 29/08/2014, 11:58 \\ ESPN.com.br
}
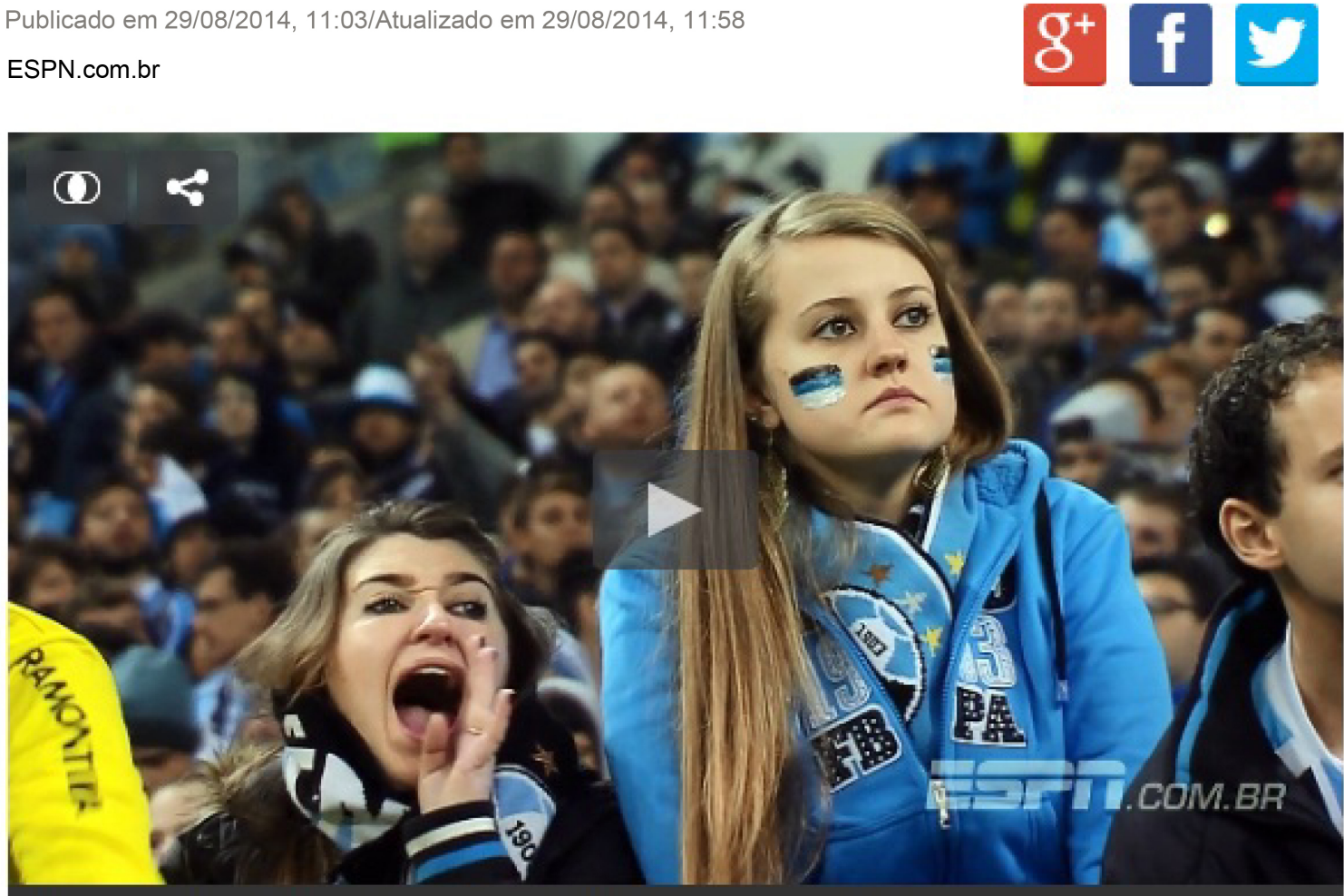

Torcedores do Grêmio proferem insultos racistas a Aranha, goleiro do Santos

Figure 1. http://espn.uol.com.br/noticia/436121_torcedora-racista-do-gremio-e-afastada-do-trabalho-diz-jornal.

stands, as that supporting the demand for fans who have offended Spider goalkeeper with racist words. So recovery is a supporter of the scene, as can be clearly seen by the image, shouts “Monkey! Monkey!". The images come back to the field, and the game is stopped, players talking, repeats the offense the scene rendered by the twisters again scenes of the crowd, and the video ends by repeating part of speech of the twisters. Thus, in the frontal plane is presented three times for two minutes and eleven seconds of video, you can see the prominence given by the media sender, establishing the woman as if the protagonist. Thus, it is the understanding of the narratives of which this subject participates in understanding the effects of the meaning of this manifestation.

The subject act second roles that shape dependent on the interaction of regimes involved. In the joint narratives (programming and strategy), we have the subject in different power relations and mediated objects. In the union of the order of relations (accident and adjustment), the subjects act without hierarchy. The narrative sequences may operate and generally from ellipses that cross the four regimes in relation assump- 
tion logic between them. It is no different in this case, by taking the twisters as a subject that interacts with the player with the fans which is a part, with the media and society. In each case, one of the regimes is mandatory which puts into question rules according to which this subject acts in the demonstration.

At first, this supporter can be understood as the most frequent thematic roles of the Brazilian scene. As such, certain procedures, actions, demonstrations are expected of surfactant, according to the definition of Semiotics Dictionary, the "theme" entry (Greimas \& Courtes, 2008: p. 496).

"It is understood by thematic role to representation under the actantial form, a theme or a theme route. The thematic role is simultaneously obtained by: 1) reducing a discourse setting a path only figurative, and furthermore, an appropriate agent that virtually subsumes; and 2) determining its position on the actor's path, a position to be set for the thematic role one isotopy need."

The thematic role involves a regular action, introducing the subject of the programming interaction scheme (Landowski, 2006). Thus, twisters, amid the crowd of his team, operate according to generally accepted standards and expected to stimulate the team, protests against referee attitudes that harm his club celebrations.

But these attitudes when considered afetual and emotional environment to which we referred before, can lead the subject to behaviors that go beyond this role, or exaggerate its manifestations, against other social thematic roles, such as citizen, a member of a shared society which tolerance is essential and its opposite inadmissible. It seems to be the case of twisters, which in the mass inflammation, is infected by the manifestation of elements of his home crowd against the goalkeeper, no longer considered in its role athlete, but as a subject segregated by race prejudice. Contagion is characteristic of the adjustment scheme (Landowski, 2006: p. 46), in which “... The principles of interaction emerge little bit of the same interaction, depending on what each participant is and, more precisely, as we shall see, because of what they feel in the way of acting of his co-participant or his opponent."

By shouting "monkey" and be caught by the camera, the cheerleader takes the cry of the crowd, but his camouflage the crowd of fans is undone by making the media sender camera. Not a participant in a large group that can hide inflamed attitudes and excesses, it goes to the individual condition that breaks the thematic role of the citizen, disregarding the other on the legal status that protects and which the athlete uses, having been offended personal and professionally. Guy infected by the crowd, perfectly aligned with the group in the first case, a woman goes to the catastrophic condition of the subject, generator accident that contradicts citizen programming. The crash of the system is characterized by risk breaching sense the discontinuity.

The story then goes on, the sanction of the media sender, which in its clear role strategist based on intentionality, develops the narrative program manipulation. The video is not about sports and even the football occupies any part of the scene, the goal is no longer the crowd of value, the viewers of the narrators. The video has journalistic tone, as a scoop, making viewers believe in the responsibility of the sender. The commentator 
points out the glaring given by the camera, reinforcing this recording capacity of fact. Meanwhile, twisters, after uttering offensive words, slightly looks away, and outlines a smile, it can be assumed, it is not given the satisfaction of having said such offenses, but have noticed the glaring camera. She continues with this attitude, expressing still be in the thematic role of a cheerleader at the same time protected by the crowd, but proud and a little embarrassed to have been filmed, as shown by his gesture to tighten the scarf that brings the club logo on chest.

Meanwhile, the locution denounces, not highlighting this gesture, but his speech, identified by lip reading, which would bear the legal penalties later, since returning to Brazilian citizen program must obey the nation's rules. The video operates; therefore, for a narrative sequence I of the program, through the adjustment amounts to the accident, was taken on strategy and back to fit in with the schedule, performing the implied ellipse in the dynamics of meaning regimes and interaction.

\section{Final Considerations}

This study aimed to present in a particular case the presence of racism in football and its reverberations in the consumer society. We have seen that when incorporated into various groups, becoming a defining national identity, football has a lot to say about the social relations of Brazil. In this sense, although this sport has been a key element of a social and economic rise of blacks and mulattos, contributing to the formation of a racial democracy is still vulnerable to the racist ideology dominant in Brazil. This appears under the guise of "racial democracy" in which prejudice is concealed by an alleged assimilation of all colors, in a culture that does not have white or black, but a mixture of all races. The media disclosure of the controversial case described here is an instructive example of this assumption.

The alleged carnivalization of prejudice and its association to what would be a simple name, belongs to the sphere of cultural imagery of Brazilian racial democracy, revealing a light and fun language to address a problem that for years has been the hallmark of the suffering of countless blacks. Speaking in Foucault's terms (Foucault, 1979), the media action appears as a "device", the techniques, strategies and forces present mechanisms in their speeches reveal the logic value of a society in which communication, image, and consumption make if interchangeable and indispensable, creating a language that can only be of seduction, of affection and irony. It could not be different as members of modern societies are primarily shaped by the "duty to play the role of consumer" (Bauman, 1999: p. 88) and not citizens. The fan is, accordingly, a consumer product of football and its derivatives, such as championships licensed products, sponsors, and even players' images.

The two most remarkable Foucault annual courses of which this is true were those of 1978 and 1979, entitled respectively "Security, territory and population", and "The birth of biopolitics". Foucault believes that modern racism is not merely an irrational prejudice, a form of socio-political discrimination, or an ideological motive in a political doctrine; rather, it is a form of government that is designed to manage a population 
(Foucault, 1997: p. 89).

The revolution in communication, reflecting in business investment, makes football be thought by many sports professionals, more like a business on the rise (Santos, 2004). In this case, the symbiosis among football, media and capitalism is no accident, but an extension of a larger phenomenon; that is, the visibility has become not only password for existence, but also currency trading and surveillance of all about all.

It is confirmed by the analysis, the position of Da Matta, according to which football produces a discontinuity - at the same time it is the simulacrum of the rules of good social life produces moments of afetual order (according to the author), which we can relate to the junction of the order interaction procedures. Thus, certain social phenomena are processed between subjects, generating controversial facts, which supplant the social roles expected of each. This is what happens in the case, when a fan manifests without respect to the social role to play, along the lines of citizenship and collective respect, restricting that it is an echo of a small crowd and ignoring the wider universe that surrounds.

\section{Acknowledgements}

This work was supported by the Pontifícia Universidade Católica de São Pauloand Fundacentro.

\section{References}

Abrahão, B. O. de L., \& Soares, A. J. G. (2009). O elogio ao negro no espaço do futebol: Entre a integração pós-escravidão e a manutenção das hierarquias sociais. Revista Brasileira de Ciências Do Esporte, 30, 9-23.

Bauman, Z. (1999). Globalização: As consequëncias humanas. Rio de Janeiro: Zahar.

Damatta, R. (1994). Antropologia do óbvio-Notas em torno do significado social do futebol brasileiro. Revista USP, No. 22, 10. https:/doi.org/10.11606/issn.2316-9036.v0i22p10-17

Fernandes, F. (1980). Fundamentos empíricos da explicação sociológica. São Paulo: Edusp.

Foucault, M. (1997). Nascimento da biopolítica. In Resumo dos cursos do Collège de France (1970-1982) (pp. 87-97). Rio de Janeiro: Jorge Zahar.

Gordon Jr., C. (1996). "Eu já fui preto e sei o que é isso"-História social dos negros no futebol brasileiro: segundo tempo. Pesquisa de Campo, 3-4, 65-78.

http://www.ludopedio.com.br/rc/index.php/biblioteca/recurso/265

Greimas, A. J., \& Courtes, J. (2008). Dicionário de semiótica. São Paulo: Contexto.

Helal, R. (2011). Futebol e comunicação: A consolidação do campo acadêmico no Brasil. Comunicação Mídia E Consumo, 8, 11-37. http://revistacmc.espm.br/index.php/revistacmc/article/view/208

Landowski, E. (1992). A sociedade refletida: Ensaios de sociossemiótica. São Paulo: EDUC.

Landowski, E. (2002). Presenças do outro: Ensaios de sociossemiótica. São Paulo: Perspectiva.

Landowski, E. (2006). Les interactions risquées. Limoges, France: Presses universitaires de Limoges.

Lima, J. A. (2014). Neymar precisa do bom-mocismo fabricado das agências? http://www.esportefinal.com.br/neymar-macacos-banana-loducca/

Nogueira, O. (2007). Preconceito racial de marca e preconceito racial de origem: Sugestão de um 
quadro de referência para a interpretação do material sobre relações raciais no Brasil. Tempo Social, 19, 287-308. https:/doi.org/10.1590/S0103-20702007000100015

Raupp, F. M., \& Beuren, I. M. (2006). Metodologia da pesquisa aplicável às Ciências Sociais. In I. M. Beuren (Ed.), Como Elaborar Trabalhos Monográficos em Contabilidade: Teoria e Prática (3rd ed., pp. 76-97). São Paulo: Atlas.

Santos, T. C. (2004). Dos espetáculos de massa às torcidas organizadas: Paixão, rito e magia no futebol. São Paulo: Annablume.

Tonini, M. D. (2012). Racismo no futebol brasileiro: revisitando o caso Grafite/Desábato. Revista de História Regional, 17, 438-468. https:/doi.org/10.1590/S0103-20702007000100015

http://www.ludopedio.com.br/rc/index.php/biblioteca/recurso/1364

Submit or recommend next manuscript to SCIRP and we will provide best service for you:

Accepting pre-submission inquiries through Email, Facebook, LinkedIn, Twitter, etc. A wide selection of journals (inclusive of 9 subjects, more than 200 journals)

Providing 24-hour high-quality service

User-friendly online submission system

Fair and swift peer-review system

Efficient typesetting and proofreading procedure

Display of the result of downloads and visits, as well as the number of cited articles Maximum dissemination of your research work

Submit your manuscript at: http://papersubmission.scirp.org/

Or contact ajc@scirp.org 